\title{
A Taxonomic Study of Heterotrophic Halophilic and Non-halophilic Bacteria from a Solar Saltern
}

\author{
By M. C. MARQUEZ, A. VENTOSA* AND F. RUIZ-BERRAQUERO \\ Department of Microbiology, Faculty of Pharmacy, University of Sevilla, Sevilla, Spain
}

(Received 27 May 1986; revised 21 July 1986)

\begin{abstract}
A total of 564 strains of heterotrophic non-halophilic, marine, moderately halophilic and extremely halophilic bacteria was isolated from a saltern located near Huelva, SW Spain, facing the Atlantic Ocean. With the exception of the extremely halophilic bacteria, these were analysed by numerical techniques using the simple matching $\left(S_{S M}\right)$ coefficient and clustering was achieved using the unweighted pair group method with averages (UPGMA) algorithm. At the $72.5 \%$ similarity level, a different number of phenons was found for each salinity group of bacteria. Of the 154 non-halophilic strains, the majority were recovered in 10 phenons, representing members of the genera Staphylococcus, Bacillus and Micrococcus. The 138 marine strains, with the exception of 24 strains, clustered into 12 phenons; seven phenons were assigned to the suprageneric grouping Pseudomonas-Alteromonas-Deleya, and the other phenons to Micrococcus, Staphylococcus, Bacillus and Vibrio. The 140 moderately halophilic strains grouped into eight phenons, with only 11 strains left unassigned. The majority of these isolates were assigned to the genus Deleya (two phenons) and they showed great similarity with the recently described species $D$. halophila, isolated from hypersaline soils. Four phenons comprised microorganisms with phenotypic characteristics very similar to the moderately halophilic Vibrio costicola. Two phenons were assigned to the genera Flavobacterium and Acinetobacter but these strains were not similar to previously described species. Of the 145 extremely halophilic isolates studied, the most important group was identified as belonging to the species Halobacterium salinarium (86 strains), followed by $H$. saccharovorum (20 strains), $H$. vallismortis (19 strains), Haloarcula hispanica (12 strains) and Halobacterium mediterranei ( 7 strains). Only one coccus was isolated, with characteristics very similar to those of Halococcus morrhuae.
\end{abstract}

\section{INTRODUCTION}

Micro-organisms can be assigned to different categories according to their salt response (Larsen, 1962; Gibbons, 1969; Kushner, 1978, 1985): (i) non-halophiles, which grow best in media containing less than $1 \%(\mathrm{w} / \mathrm{v})$ total salts; some are able to tolerate high salt concentrations and are considered halotolerant; (ii) slight halophiles, which grow best in media containing $1-3 \%(\mathrm{w} / \mathrm{v})$ salt and include the marine bacteria; (iii) moderate halophiles, which grow best in media containing $3-15 \%(\mathrm{w} / \mathrm{v})$ salt; (iv) borderline extreme halophiles, which grow best in media containing 9-23\% (w/v) salt; and (v) extreme halophiles, which grow best in media containing $15-32 \%(\mathrm{w} / \mathrm{v})$ salt. Both moderate and extreme halophiles are found in hypersaline lakes (Elazari-Volcani, 1940; Brisou et al., 1974; Nissenbaum, 1975; Post, 1977) and in solar salterns (Davis, 1978; Rodriguez-Valera et al., 1981, 1985; Javor, 1984), but only a few studies have attempted to describe the non-halophilic or slightly halophilic bacteria found in these habitats (Brisou et al., 1974). The aim of this study was a comparison of extremely and moderately halophilic bacteria present in a solar saltern located near the Atlantic Ocean with those previously described from salterns located near the Mediterranean Sea (Ventosa et al., 1982, 1983; Rodriguez-Valera et al., 1985). In order to have a more complete understanding of the bacteria that can live in this hypersaline habitat, we have also studied non-halophilic and marine heterotrophic bacteria in this environment. 


\section{METHODS}

Isolation of strains. The micro-organisms were isolated from the water of ponds of a solar saltern located near Huelva, SW Spain, between July 1983 and April 1984. Samples were collected from ponds of the saltern in sterile plastic tubes and were plated as soon as possible (not more than $6 \mathrm{~h}$ after collection). The salt concentrations of the ponds of the saltern were very different depending on the season of the year, varying between $4.8 \%(w / v)$ total salts and salt saturation.

Four physiological groups of heterotrophic bacteria were studied using the following isolation media (compositions given as $\%$,w/v). (i) For non-halophilic bacteria: yeast extract (Difco), 1 ; proteose-peptone no. 3 (Difco), 0.5 ; glucose, 0.1 ; agar (technical) (Oxoid), $1.5 ; \mathrm{pH} 7.2$ adjusted with $1 \mathrm{M}-\mathrm{NaOH}$. (ii) For marine bacteria: $\mathrm{NaCl}, 2.34 ; \mathrm{MgSO}_{4} .7 \mathrm{H}_{2} \mathrm{O}, 0.61 ; \mathrm{MgCl}_{2} .6 \mathrm{H}_{2} \mathrm{O}, 0.39 ; \mathrm{KCl}, 0.06 ; \mathrm{CaCl}_{2} .2 \mathrm{H}_{2} \mathrm{O}, 0.01 ; \mathrm{NaBr}, 0.007 ; \mathrm{NaHCO}_{3}$, 0.002 ; yeast extract (Difco), 1; proteose-peptone no. 3 (Difco), 0.5 ; glucose, $0 \cdot 1$; agar (technical) (Oxoid), $1.5 ; \mathrm{pH}$ adjusted to 7.2 with $1 \mathrm{M}-\mathrm{NaOH}$. (iii) For moderately halophilic bacteria: $\mathrm{NaCl}, 17 \cdot 8 ; \mathrm{KCl}, 0.2 ; \mathrm{MgSO}_{4} .7 \mathrm{H}_{2} \mathrm{O}, 0 \cdot 1$; $\mathrm{CaCl}_{2} .2 \mathrm{H}_{2} \mathrm{O}, 0.036 ; \mathrm{NaBr}, 0.023 ; \mathrm{NaHCO}_{3}, 0.006 ;$ yeast extract (Difco), $1 ;$ proteose-peptone no. 3 (Difco), 0.5; glucose, $0 \cdot 1$; agar (technical) (Oxoid), $1.5 ; \mathrm{pH} 7.2$ adjusted with $1 \mathrm{~m}-\mathrm{NaOH}$. This medium has been shown to be very selective for moderate halophiles because of its low $\mathrm{Mg}^{2+}$ content, which does not support good growth of extreme halophiles (Ventosa et al., 1982). (iv) For extremely halophilic bacteria: $\mathrm{NaCl}, 19 \cdot 5 ; \mathrm{MgSO}_{4} .7 \mathrm{H}_{2} \mathrm{O}, 5 \cdot 06$; $\mathrm{MgCl}_{2} .6 \mathrm{H}_{2} \mathrm{O}, 3.25 ; \mathrm{KCl}, 0.5 ; \mathrm{CaCl}_{2} .2 \mathrm{H}_{2} \mathrm{O}, 0.08 ; \mathrm{NaBr}, 0.058 ; \mathrm{NaHCO}_{3}, 0.016$; yeast extract (Difco), 1 ; proteose-peptone no. 3 (Difco), 0.5 ; glucose, 0.1 ; agar (technical) (Oxoid), $1.5 ; \mathrm{pH} 7.2$ adjusted with $1 \mathrm{M}-\mathrm{NaOH}$. This medium was supplemented with $500000 \mathrm{IU}$ Pencillin $\mathrm{G}^{-1}$ to prevent good growth of non-halophilic, marine or moderately halophilic eubacteria (Rodriguez-Valera et al., 1979).

The samples were plated on the four different media either directly or after dilution in sterile water or salt solution at 3,10 or $25 \%(\mathrm{w} / \mathrm{v})$ total salts for the non-halophilic, marine, moderately halophilic and extremely halophilic bacteria, respectively. Plates were incubated in sealed plastic bags at $37^{\circ} \mathrm{C}$ for 4 to $7 \mathrm{~d}$ except for the extreme halophiles, which were incubated for $15 \mathrm{~d}$. Colonies were isolated randomly from the plates and successively subcultured in the same isolation medium to ensure purity. The numbers of isolated strains included in this study belonging to the four groups were: non-halophiles, 150; marine bacteria, 134; moderate halophiles, 135; and extreme halophiles, 145.

Reference strains. The following reference strains were also included in the study: the non-halophilic bacteria Arthrobacter globiformis CCM $1651^{\mathrm{T}}$ (T denotes type strain), Bacillus megaterium CCM $2007^{\mathrm{T}}$, Micrococcus luteus CCM $169^{\mathrm{T}}$ and Staphylococcus aureus CCM 885 ${ }^{\mathrm{T}}$; the marine bacteria Alteromonas macleodii ATCC $27126^{\mathrm{T}}$, Bacillus marinus ATCC $29841^{\top}$, Planococcus citreus CCM $2706^{\mathrm{T}}$ and Pseudomonas marina ATCC $25374^{\mathrm{T}}$; the moderately halophilic bacteria Deleya halophila $\mathrm{CCM} 3662^{\mathrm{T}}$, Flavobacterium halmephilum $\mathrm{CCM} 2833^{\mathrm{T}}$, Micrococcus halobius CCM $2591^{\mathrm{T}}$, Planococcus halophilus $\mathrm{CCM} 2706^{\mathrm{T}}$ and Vibrio costicola $\mathrm{NCMB} 701^{\mathrm{T}}$; and the extremely halophilic bacteria Haloarcula hispanica ATCC $33960^{\mathrm{T}}$, Halobacterium mediterranei ATCC $33500^{\mathrm{T}}, H$. saccharovorum ATCC $29252^{\mathrm{T}}, H$. salinarium CCM 2088, H. vallismortis ATCC $29715^{\mathrm{T}}, H$. volcanii CCM $2852^{\mathrm{T}}$ and Halococcus morrhuae CCM $537^{\mathrm{T}}$.

Maintenance media. For non-halophilic and marine bacteria the maintenance medium was the same as the isolation medium. The medium used for maintenance of moderate and extreme halophiles was as follows $(\%, w / v)$; yeast extract (Difco), 1; proteose-peptone no. 3 (Difco), $0 \cdot 5$; glucose, $0 \cdot 1$; agar (technical) (Oxoid), $1 \cdot 5$; and salts solution according to Subow (1931) to give final concentrations of 10 and $25 \%(\mathrm{w} / \mathrm{v})$, respectively. The $\mathrm{pH}$ was adjusted to 7.2 with $1 \mathrm{M}-\mathrm{NaOH}$.

Characterization of isolates. A total of 55 phenotypic characteristics was determined for each strain of nonhalophilic, marine and moderately halophilic bacteria. The characteristics were as follows: Gram reaction; cell morphology; spore formation; motility; growth with total salts concentrations of $0,0 \cdot 5,3,5,10,15,20,25$ and $30 \%$ $(\mathrm{w} / \mathrm{v})$; aerobic and anaerobic growth; catalase and oxidase production; acid production from glucose, lactose, mannitol, sorbitol and sucrose; indole production; reaction in the methyl red, Voges-Proskauer and Simmon's citrate tests; nitrate and nitrite reduction; $\mathrm{H}_{2} \mathrm{~S}$ production; hydrolysis of gelatin, casein, starch, Tween 80 and aesculin; DNAase production; utilization of compounds as sole source of carbon and energy (aesculin, D-fructose, D-glucose, lactose, maltose, sucrose, glycerol, D-mannitol; citrate, fumarate, malate, pyruvate, propionate, succinate; L-arginine, L-glutamic acid, L-histidine, L-lysine, L-ornithine, L-tryptophan). For extremely halophilic bacteria a total of 26 characteristics was determined for each strain (morphology; pigmentation; motility; growth with $0-30 \%, \mathrm{w} / \mathrm{v}$, total salts; aerobic and anaerobic growth; catalase and oxidase production; acid production from glucose, lactose, mannitol, sorbitol and sucrose; nitrate and nitrite reduction; $\mathrm{H}_{2} \mathrm{~S}$ production; hydrolysis of gelatin, starch and Tween 80). The tests were done as previously described (Ventosa et al., 1982; Quesada et al., 1983, 1984; Rodriguez-Valera et al., 1983). Incubation was at $37^{\circ} \mathrm{C}$ for up to $7 \mathrm{~d}$ except for the extreme halophiles (up to $15 \mathrm{~d}$ ). The media used contained, as appropriate, $0 \cdot 5,3,10$ or $25 \%(w / v)$ total salts, using the salt mixture described by Ventosa et al. (1982).

Numerical analysis. Differential features were used for a numerical analysis. Positive and negative results were coded as 1 and 0 , respectively; noncompatible or missing data were coded as 9 . The data were examined separately 
for each physiological group by using the simple matching (Sokal \& Michener, 1958) and Jaccard (Jaccard, 1908) coefficients, and clustering was achieved by unweighted average linkage (Sneath \& Sokal, 1973), using the MINT program of F. J. Rolf (Department of Ecology and Evolution, State University of New York at Stony Brook, Stony Brook, NY, USA). Cophenetic correlations were also obtained (Sneath \& Sokal, 1973). The test error was evaluated by examining 12 strains of each group in duplicate (Sneath \& Johnson, 1972). Computations were done with a UNIVAC model 1108 computer in the Computer Centre, University of Sevilla.

\section{RESULTS}

Tables showing the tests applied and frequencies of positive characters for non-halophilic, marine, moderately halophilic and extremely halophilic bacteria have been deposited with the British Library Lending Division, Boston Spa, Yorkshire LS23, 7BQ, UK, as Supplementary Publication no. SUP 28023 (8 pp.).

\section{Non-halophilic bacteria}

The results of the numerical study of the selected strains using the simple matching $\left(S_{S M}\right)$ coefficient, clustered by the unweighted average linkage method (UPGMA), gave the dendrogram shown in Fig. 1. Ten phenons containing three or more strains were defined at $72.5 \%$ similarity; 16 strains did not cluster at this similarity level. The estimated test error was less than $3.5 \%$, which would not significantly affect the cluster analysis. The cophenetic correlation was $0 \cdot 86089$. The Jaccard coefficient $\left(S_{J}\right)$ was also used, but the cluster composition was not markedly affected

Phenon A-1. The nine strains included in this group were clustered at the $75 \%$ similarity level. They were Gram-positive, non-spore-forming cocci, non-motile, strictly aerobic, and catalase positive; nitrate and nitrite were not reduced. Acid was not produced from the sugars studied. Indole was not produced. The methyl red and Simmon's citrate tests were negative. The strains were not caseinolytic. Very few compounds were utilized as sole source of carbon and energy. This group clearly belongs to the family Micrococcaceae, and could be placed in the genus Micrococcus (Buchanan \& Gibbons, 1974).

Phenon A-2. This group of eight strains was very similar to phenon A-1. The strains were Gram-positive, non-spore-forming cocci, strictly aerobic, non-motile and oxidase negative. Acid was produced from all the sugars studied. Four strains reduced nitrate but not nitrite. Indole was not produced. Lipolytic activity was not detected. These strains could also be assigned to the genus Micrococcus, but they could use more organic compounds as sole source of carbon and energy than could the strains in phenon A-1.

Phenon A-3. This phenon contained 70 strains related at a similarity level of $75 \%$. The strains were Gram-positive, non-motile cocci, catalase positive and oxidase negative, and facultatively anaerobic. The methyl red and Voges-Proskauer tests were positive. Indole was not produced. Acid was produced from sugars. Aesculin was not hydrolysed. Most strains were not lipolytic. Only some carbohydrates and alcohols were used as sole source of carbon and energy. Amino acids were not used. This group clearly belong to the family Micrococcaceae, and could be placed in the genus Staphylococcus (Buchanan \& Gibbons, 1974).

Phenon A-4. This contained five strains related at a similarity level of $88 \%$. They were nonmotile cocci, facultatively anaerobic, and catalase and oxidase (except one strain) positive. The methyl red and Simmon's citrate tests were negative. Indole and acetoin were not produced. Neither nitrate nor nitrite was reduced. Starch was hydrolysed. The strains were not caseinolytic or lipolytic. They were able to use more organic compounds for growth than strains included in phenon A-3. These strains could be also included in the genus Staphylococcus.

Phenon $A-5$. The three strains included in this phenon were Gram-positive rods, endosporeforming, motile, and catalase positive. The methyl red test was negative. Indole and acetoin were not produced. Nitrite was not reduced and only one strain was able to reduce nitrate. Acid was not produced from glucose, lactose, mannitol, sorbitol or sucrose. The strains were able to 


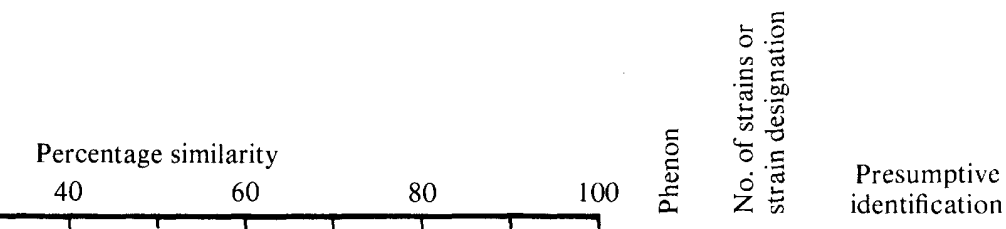

Fig. 1. Simplified dendrogram showing the clustering of strains into 10 phenons based on the $S_{S M}$ coefficient and UPGMA clustering, for 150 non-halophilic bacteria isolated from a solar saltern and four reference strains. 
hydrolyse gelatin but not casein, Tween 80 or aesculin. Numerous compounds were utilized as sole source of carbon and energy. This group clearly belong to the family Bacillaceae, and could be placed in the genus Bacillus (Buchanan \& Gibbons, 1974).

Phenon $A-6$. The three strains included in this phenon clustered at a similarity level of $77 \%$. They were Gram-positive rods, spore forming, motile (except one strain), catalase and oxidase positive, and strictly aerobic. Nitrate but not nitrite was reduced. Acid was produced from glucose (except by one strain) but not from the other sugars studied. Indole and acetoin were not produced; the methyl red test was negative. Two of the three strains produced $\mathrm{H}_{2} \mathrm{~S}$. They were all able to hydrolyse gelatin and starch but not casein, Tween 80 or aesculin. In contrast to the previous phenon, these strains were able to use only some organic compounds for growth. These strains could also be assigned to the genus Bacillus.

Phenon A-7. This group of seven strains was very similar to phenon A-6. Most of the strains were non-motile rods and oxidase negative. Acid was produced only from glucose. $\mathrm{H}_{2} \mathrm{~S}$ was not produced. These strains could also be assigned to the genus Bacillus.

Phenon A-8. This group included 15 strains which were Gram-positive, endospore-forming rods; the majority were motile. Acid was produced from sugars. Nitrite was not reduced. Except for one strain, indole was not produced. Simmon's citrate test was positive. Aesculin was hydrolysed but not Tween 80 . Numerous compounds were utilized as sole carbon and energy source. These strains could also be assigned to the genus Bacillus.

Phenon A-9. This phenon, containing seven strains, was very similar to phenon A-8, but the strains differed in: acid production from sorbitol, Simmon's citrate, $\mathrm{H}_{2} \mathrm{~S}$ production and aesculin hydrolysis. These strains could also be assigned to the genus Bacillus.

Phenon $A-10$. Eleven strains were clustered in this group; all were Gram-positive rods, endospore forming, and catalase and oxidase positive. Most were motile. Acid was produced from all the sugars studied. Indole and methyl red tests were negative. Nitrate but not nitrite was reduced; $\mathrm{H}_{2} \mathrm{~S}$ was produced. The strains were able to hydrolyse gelatin, starch and aesculin but not casein or Tween 80 . These strains could also be assigned to the genus Bacillus.

\section{Marine bacteria}

The results of the numerical study of the characteristics of the strains grouped by means of the $S_{S M}$ coefficient and UPGMA clustering yielded the dendrogram shown in Fig. 2. The cophenetic correlation was 0.82426 . The estimated error was less than $4.0 \%$, which would not significantly affect the cluster analysis. The majority of the strains were grouped into 12 phenons at $72.5 \%$ similarity; 24 strains, four of which were reference strains, clustered separately.

Phenons $B-1, B-2, B-3, B-4, B-5, B-7$ and $B-9$. The numbers of strains included in these phenons were $6,16,6,3,3,9$ and 42 , respectively; all the strains showed very similar phenotypic characteristics. All were non-spore forming rods, and most were Gram-negative, motile, strictly aerobic and catalase positive. The three strains in phenon B-5 were oxidase negative, but most of the strains in the others phenons were oxidase positive. Acid was not produced from the sugars studied, except in the case of the strains in phenon B-5. Nitrite was reduced. Indole production was negative. For the majority of the strains the methyl red and Voges-Proskauer tests were negative; casein was not hydrolysed. All were able to utilize numerous compounds as sole carbon and energy source. These strains could be assigned to the suprageneric grouping PseudomonasAlteromonas-Deleya.

Phenon B-6. This group included eight strains which were Gram-positive cocci, non-motile, non-spore-forming and catalase positive. All but two strains were oxidase negative. Most were facultatively aerobic. Indole production, Simmon's citrate and Voges-Proskauer tests were negative. Most strains were able to reduce nitrate but not nitrite. Numerous organic compounds were used for growth. These strains may be placed in the genus Staphylococcus. 


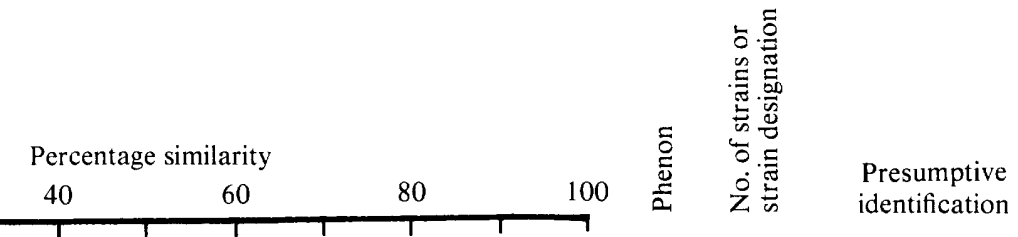

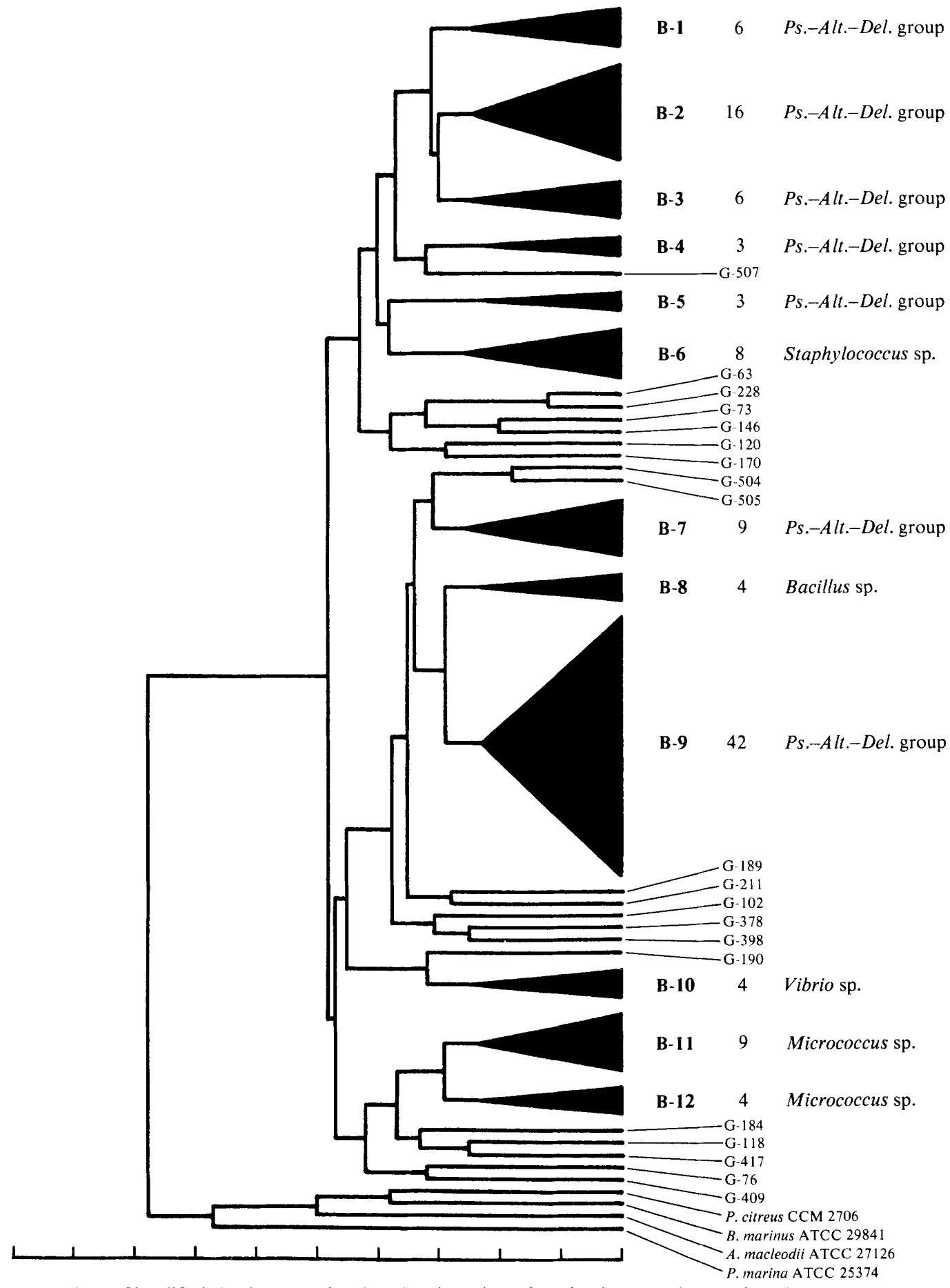

Fig. 2. Simplified dendrogram showing the clustering of strains into 12 phenons based on the $S_{S M}$ coefficient and UPGMA clustering, for 134 marine bacteria isolated from a solar saltern and four reference strains. Ps. - Alt - Del . group $=$ Pseudomonas - Alteromonas - Deleya group. 
Phenon B-8. This phenon contained only four strains. They were Gram-positive rods, endospore-forming and catalase positive. Except for one strain, they were non-motile and oxidase positive. All were strictly aerobic. Acid was produced from sucrose (except by one strain) but not from the other sugars studied. The methyl red test was negative. Nitrite was not reduced. The strains were lipolytic but not caseinolytic. $\mathrm{H}_{2} \mathrm{~S}$ was produced. Few compounds were used as sole source of carbon and energy. This phenon can be placed in the genus Bacillus.

Phenon $B-10$. The four strains in this phenon were motile, Gram-negative rods, non-sporeforming, and catalase and oxidase positive. They were facultatively anaerobic, $\mathrm{H}_{2} \mathrm{~S}$ producers and proteolytic. Nitrate and nitrite were not reduced. The methyl red and DNAase tests were positive. Indole production and the Simmon's citrate test were negative. Numerous compounds were utilized as sole carbon and energy source. All members of this phenon were assigned to the genus Vibrio.

Phenons $B-11$ and $B-12$. The 13 strains included in these two phenons were Gram-positive cocci, non-spore-forming, non-motile and catalase positive. All except one strain were oxidase negative and strictly aerobic. Indole was not produced. Nitrite was not reduced. The DNAase test and aesculin hydrolysis were negative. Numerous compounds were used as sole carbon and energy source. These strains could be included in the genus Micrococcus.

\section{Moderately halophilic bacteria}

The results of the numerical study of the characteristics of the strains grouped by means of the $S_{S M}$ coefficient and UPGMA clustering yielded the dendrogram shown in Fig. 3. The cophenetic correlation was 0.84801 . The estimated error was less than $3.5 \%$, which would not significantly affect the cluster analysis. The majority of the strains were grouped into eight phenons at $72.5 \%$ similarity. Eleven strains, five of which were reference strains, clustered separately.

Phenon C-1. This group included 36 strains which were Gram-negative, motile rods, and catalase positive. Most were oxidase positive and strictly aerobic. Only some strains were able to produce acid from sugars. Indole and acetylmethylcarbinol were not produced. The methyl red test was negative. Most strains were able to reduce nitrate but not nitrite. Gelatin, casein, starch and Tween 80 were not hydrolysed. Certain carboxylic acids were used as sole source of carbon and energy. These strains were very similar to the species Deleya halophila (Quesada et al., 1984).

Phenon $C$-2. This group comprised 35 strains that clustered at the $74 \%$ similarity level. They were Gram-negative rods; most were motile ( 31 strains), oxidase positive ( 29 strains) and strictly aerobic (30 strains). Acid was produced from glucose but not from the other sugars studied. These strains were very similar to those of phenon C-1. Most were able to reduce nitrate but not nitrite. These strains were able to use only some organic compounds for growth. They could also be included in the genus Deleya.

Phenon $C$-3. This group included 14 strains which were Gram-negative, motile rods, catalase and oxidase positive, and facultatively anaerobic. Acid was produced from most of the sugars tested. Only one strain included in this phenon was able to produce indole. The VogesProskauer test was positive. Nitrate and nitrite were not reduced. $\mathrm{H}_{2} \mathrm{~S}$ and DNAase were produced. Gelatin but not Tween 80 was hydrolysed. None of the organic compounds tested was used as sole source of carbon and energy. This group clearly belongs to the family Vibrionaceae, and could be placed in the genus Vibrio (Baumann \& Schubert, 1984).

Phenon C-4. This group of 16 strains was very similar to phenon C-3. Indole was not produced. Only some carboxylic acids and amino acids were used as sole source of carbon and energy; carbohydrates were not used. These strains could also be assigned to the genus Vibrio.

Phenon C-5. The five strains included in this group were clustered at the $81 \%$ similarity level. This group was very similar to phenons C -3 and C-4 but the strains were not able to produce acid from glucose, mannitol or sorbitol, and only a few strains produced acid from lactose and 


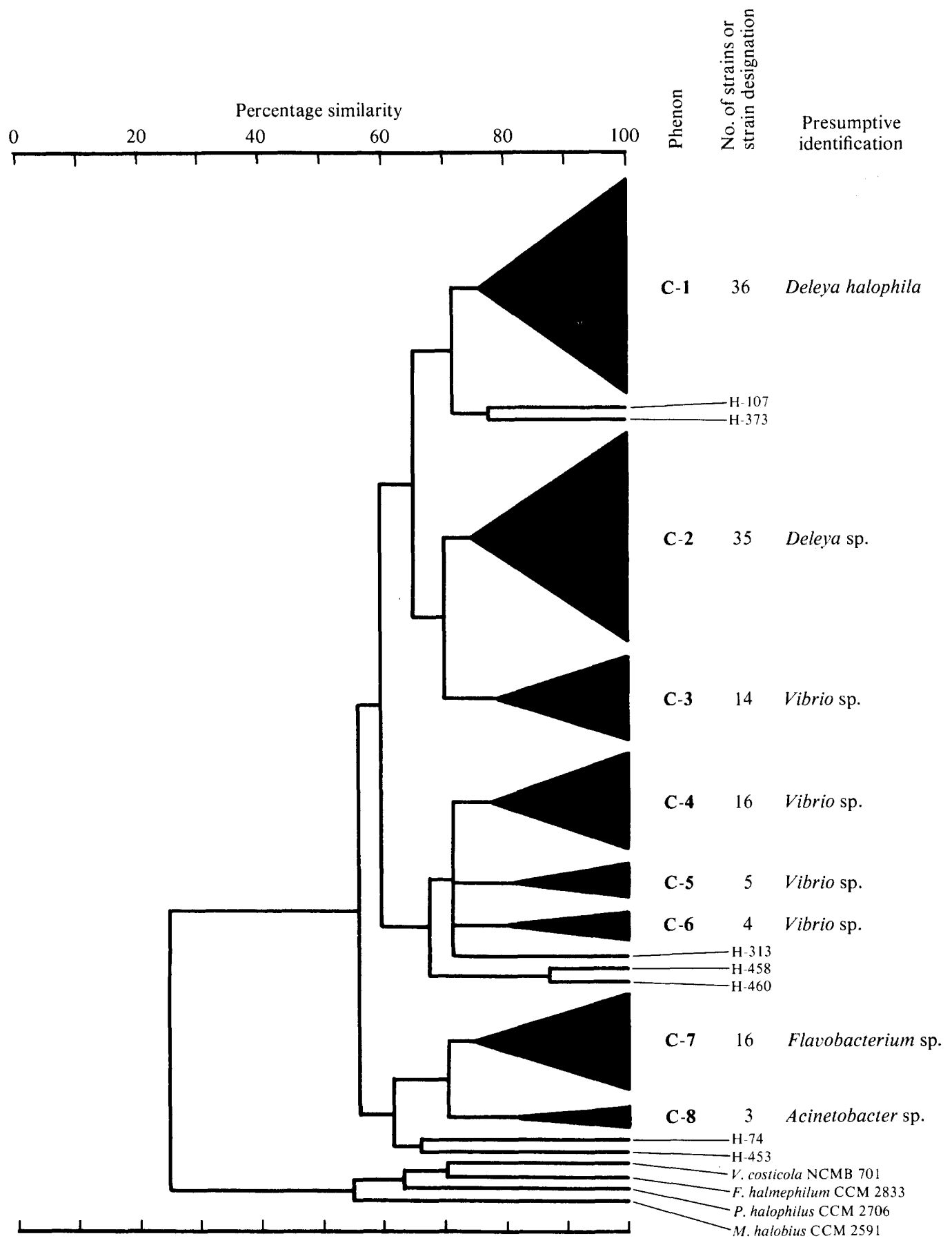

Fig. 3. Simplified dendrogram showing the clustering of strains into eight phenons based on the $S_{S M}$ coefficient and UPGMA clustering, for 135 moderately halophilic bacteria isolated from a solar saltern and five reference strains. 
sucrose. The indole and Simmon's citrate tests were negative. Nitrate and nitrite were not reduced. Gelatin was hydrolysed, but not starch or Tween 80 . These strains could also be assigned to the genus Vibrio.

Phenon C-6. This group of four strains was very similar to phenon C-3. Simmon's citrate reaction was positive. Casein, starch and Tween 80 were not hydrolysed. Only some alcohols, carboxylic acids and amino acids could be used as sole source of carbon and energy. This group could also be placed in the genus Vibrio.

Phenon C-7. This contained 16 strains related at a similarity level of $75 \%$. They were Gramnegative rods, strictly aerobic and catalase positive. Most were motile ( 15 strains) and oxidase positive (10 strains). Only some strains were able to produce acid from sugars. The indole, methyl red and Voges-Proskauer tests were negative. Gelatin, casein, starch and Tween 80 were not hydrolysed. Numerous compounds were utilized as sole source of carbon and energy. This group could be placed in the genus Flavobacterium (Holmes et al., 1984).

Phenon $C-8$. This group contained three strains which were Gram-negative, non-motile rods, catalase positive and oxidase negative, and strictly aerobic. They were not able to produce acid from the sugars tested. The methyl red test was negative. Indole and acetylmethylcarbinol were not produced. Simmon's citrate reaction was positive. Nitrite was not reduced. Gelatin was hydrolysed, but not casein, starch or Tween 80. All six carboxylic acids tested were used as sole source of carbon and energy. This group clearly belongs to the family Neisseriaceae, and could be placed in the genus Acinetobacter (Bøvre, 1984).

\section{Extremely halophilic bacteria}

A total of 145 extremely halophilic bacteria was isolated and characterized. Due to the low number of phenotypic features determined, they were not submitted to a numerical study. Except for one coccus, all the isolates were long rods or pleomorphic cells, and the colonies were strongly red-pigmented. They were able to grow at high salt concentrations (optimal growth at $25-20 \%, \mathrm{w} / \mathrm{v}$, salts) and did not grow below $5 \%$ total salts. Thus, all the isolates are considered to be members of the Halobacteriaceae (Larsen, 1984). Their phenotypic characteristics assign them to the following species: Halobacterium salinarium (Hb. halobium), 86 strains; $H b$. saccharovorum, 20 strains; $H b$. vallismortis, 19 strains; Haloarcula hispanica, 12 strains; $H b$. mediterranei, 7 strains and Halococcus morrhuae, 1 strain.

\section{DISCUSSION}

Bacteria present in hypersaline habitats are still relatively unexplored from the taxonomic point of view. Recently, new species of moderately and extremely halophilic bacteria have been described (Juez et al., 1986; Oren, 1983a, b; Oren et al., 1984a, b; Quesada et al., 1984; Rodriguez-Valera et al., 1983; Torreblanca et al., 1986; Zeikus et al., 1983). However, the identification of bacteria present in hypersaline habitats is still difficult. This fact is shown in our study, since the reference bacteria used were not recovered in any of the phenons obtained, except in the case of Deleya halophila CCM 3662.

Most studies done in hypersaline environments have been concerned with moderately and extremely halophilic bacteria, and very few with non-halophiles. For example, in the studies done in the Great Salt Lake (Post, 1977) it is presumed that non-halophilic organisms exist, but these have not been studied. Similarly, in the Dead Sea the only reports concern the existence of non-halophilic Gram-positive spore forming bacteria (Elazari-Volcani, 1940; Nissenbaum, 1975). Davis (1978) and Rodriguez-Valera et al. (1985) did not mention the presence of nonhalophilic bacteria in their studies on salterns. Our results regarding non-halophilic bacteria provide preliminary information on these organisms in salterns. The majority of these isolates belonged to the genera Staphylococcus, Bacillus and Micrococcus. Bacteria from these genera have been described as being quite tolerant to salt (Kushner, 1978; Brisou, 1980). Our results are in agreement with those obtained by Henis \& Eren (1963) from hypersaline soils, where a predominance of isolates belonging to the genera Bacillus and Micrococcus was found, but they 
contrast with the great diversity of species found by Brisou et al. (1974) in a hypersaline lake. It is noteworthy that of the 150 non-halophilic bacteria we isolated, 75 belonged to the genus Staphylococcus. The phenotypic characteristics of these strains were very similar to those included in the phenon E-10 obtained by Gunn \& Colwell (1983), which was identified as $S$. epidermidis.

The marine bacteria present in salterns and waters with a marine origin have likewise remained largely unstudied. These bacteria are capable of withstanding high concentrations of salt (Forsyth et al., 1971) and in some cases they may compete with the moderately halophilic bacteria (Ventosa et al., 1984). In our study predominance of strictly aerobic Gram-negative rods was observed. This group has been assigned to the suprageneric grouping DeleyaAlteromonas-Pseudomonas; further studies would be necessary to identify them to the genus level. The small number of facultatively anaerobic rods belonging to the genus Vibrio is surprising when compared to the numbers found in sea water (Colwell, 1984; Sieburth, 1979). Members of the genera Micrococcus, Staphylococcus and Bacillus also appeared. The eight strains included in phenon B-6 have very similar phenotypic characteristics to $S$. epidermidis (Gunn \& Colwell, 1983). Phenon B-8, comprising four strains, has a certain similarity with Bacillus marinus (Rüger \& Richter, 1979; Rüger, 1983).

It is noticeable that the great majority of the moderately halophilic isolates were Gramnegative rods which were assigned to the genera Deleya ( 71 strains) and Vibrio ( 39 strains). The 36 strains assigned to phenon C-1, in which the reference strain Deleya halophila CCM 3662 was included, show great similarity with Deleya halophila (Quesada et al., 1984) from hypersaline soils. Phenon C-2 comprised 35 strains with characteristics similar to those of phenon C-1 except in the reduction of nitrates to nitrites, production of $\mathrm{H}_{2} \mathrm{~S}$ and hydrolysis of aesculin. The second large group of moderately halophilic bacteria in this saltern comprised strains of the genus Vibrio (phenons C-3, C-4, C-5 and C-6). The high proportion of bacteria belonging to this genus is in agreement with results obtained in a saltern from the Mediterranean Sea (Ventosa et al., 1982). The strains we isolated had phenotypic characteristics very similar to those of Vibrio costicola, the only moderately halophilic species described in this genus (Baumann et al., 1984). Phenon C7 was assigned to the genus Flavobacterium, within which a moderately halophilic species, $F$. halmephilum, has been described (Weeks, 1974). However, this species differs from our isolates in motility and hydrolysis of gelatin. Recently, some flavobacteria have been isolated from a saltern from Alicante, Spain (Quesada et al., 1985), but these differ from those studied here in being non-motile and oxidase positive. The three strains which constitute phenon C-8 were assigned to the genus Acinetobacter. This genus does not contain species described as moderately halophilic. However, other strains with characteristics similar to those of this phenon have been isolated from different saline habitats (Quesada et al., 1985) and these strains could therefore represent a new taxon. A moderately halophilic Gram-positive coccus which was not included within any phenon was also found. This strain probably belongs to the genus Micrococcus. On the other hand, bacteria with characteristics similar to those of the genera Alteromonas, Chromobacterium and Pseudomonas, found in other hypersaline habitats (Ventosa et al., 1982; Quesada et al., 1983; Rodriguez-Valera et al., 1985), were not isolated from this saltern.

Of the extremely halophilic bacteria, the major group was formed by strains with characteristics very similar to those of Halobacterium salinarium (Hb. halobium), probably due to the medium used for isolation. It has been demonstrated that these species are usually isolated on complex media and therefore the proportion of this type might have been lower if a poorer isolation medium had been used (Rodriguez-Valera et al., 1983; Torreblanca et al., 1986). The other halobacteria isolated were included in the species $H b$. saccharovorum (20 strains), $H b$. vallismortis (19 strains), Haloarcula hispanica (12 strains) and Hb. mediterranei ( 7 strains). Of the 145 extremely halophilic strains isolated, only one was identified as a Halococcus sp. Its characteristics were very similar to those of the species Hc. morrhuae (Larsen, 1984) except in $\mathrm{H}_{2} \mathrm{~S}$ production and gelatin hydrolysis. In this study no strains with characteristics similar to $H \mathrm{~b}$. volcanii and $H b$. sodomense were been isolated, which was to be expected, since these species were isolated from the Dead Sea, a habitat with athalassohaline characteristics, with a much higher proportion of magnesium salts than that found in the saltern we studied (Mullakhanbhai \& Larsen, 1975; Oren, 1983a). 
We are grateful to the Computer Centre of the University of Sevilla for their facilities and to C. Montero for his help during the course of this work. This investigation was supported by grants from the Comision Asesora para el Desarrollo de la Investigación Científica y Técnica and the Junta de Andalucia.

\section{REFERENCES}

BaumanN, P. \& Schubert, R. H. W. (1984). Family Vibrionaceae. In Bergey's Manual of Systematic Bacteriology, vol. 1, pp. 516-538. Edited by N. R. Krieg. Baltimore: Williams \& Wilkins.

BaumanN, P., Furniss, A. L. \& LeE, J. V. (1984). Genus Vibrio. In Bergey's Manual of Systematic Bacteriology, vol. 1, pp. 518-538. Edited by N. R. Krieg. Baltimore: Williams \& Wilkins.

BøVRE, K. (1984). Family Neisseriaceae. In Bergey's Manual of Systematic Bacteriology, vol. 1, pp. 288309. Edited by N. R. Krieg. Baltimore: Williams \& Wilkins

BrisoU, J. F. (editor) (1980). Les Bactéries Marines. Paris: Masson.

Brisou, J., Courtois, D. \& Fenis, F. (1974). Microbiological study of a hypersaline lake in French Somaliland. Applied Microbiology 27, 819-822.

BuchanaN, R. E. \& GibBons, N. E. (editors) (1974). Bergey's Manual of Determinative Bacteriology, 8th edn. Baltimore: Williams \& Wilkins.

COLWELL, R. R. (editor) (1984). Vibrios in the Environment. New York: Wiley.

DAvIS, J. S. (1978). Biological communities of a nutrient enriched salina. Aquatic Botany 4, 23-42.

ElAZARI-VolCANI, B. (1940). Studies on the microflora of the Dead Sea. PhD thesis, Hebrew University, Jerusalem.

Forsyth, M. P., SHINDler, D. B., GochNaUER, M. B. \& KuSHNER, D. J. (1971). Salt tolerance of intertidal marine bacteria. Canadian Journal of Microbiology 17, 825-828.

GibBons, N. E. (1969). Isolation, growth and requirements of halophilic bacteria. Methods in Microbiology 3B, 169-183.

GunN, B. A. \& Colwell, R. R. (1983). Numerical taxonomy of staphylococci isolated from the marine environment. International Journal of Systematic Bacteriology 33, 751-759.

Henis, Y. \& EReN, J. (1963). Preliminary studies on the microflora of a highly saline soil. Canadian Journal of Microbiology 9, 902-904.

Holmes, B., OWen, R. J. \& McMeekin, T. A. (1984). Genus Flavobacterium. In Bergey's Manual of Systematic Bacteriology, vol. 1, pp. 353-360. Edited by N. R. Krieg. Baitimore: Williams \& Wilkins.

JACCARD, P. (1908). Nouvelles recherches sur la distribution florale. Bulletin de la Société vaudoise des sciences naturelles 44, 223-270.

JAVOR, B. J. (1984). Growth potential of halophilic bacteria isolated from solar salt environments: carbon sources and salt requirements. Applied and Environmental Microbiology 48, 352-360.

Juez, G., Rodriguez-Valera, F., Ventosa, A. \& KUSHNER, D. J. (1986). Haloarcula hispanica spec. nov. and Haloferax gibbonsii spec. nov., two new species of extremely halophilic Archaebacteria. Systematic and Applied Microbiology 8, 75-79.

KusHNER, D. J. (1978). Life in high salt and solute concentrations: halophilic bacteria. In Microbial Life in Extreme Environments, pp. 317-368. Edited by D. J. Kushner. London: Academic Press.
KushnER, D. J. (1985). The Halobacteriaceae. In The Bacteria, vol. 8, pp. 171-214. Edited by C. R. Woese \& R. S. Wolfe. London: Academic Press.

LARSEN, H. (1962). Halophilism. In The Bacteria, vol. 4, pp. 297-336. Edited by I. C. Gunsalus \& R. Y. Stanier. London: Academic Press.

LARSEN, H. (1984). Family Halobacteriaceae. In Bergey's Manual of Systematic Bacteriology, vol. 1, pp. 261-267. Edited by N. R. Krieg. Baltimore: Williams \& Wilkins.

Mullakhanbhai, M. F. \& Larsen, H. (1975). Halobacterium volcanii spec. nov., a Dead Sea Halobacterium with a moderate salt requirement. Archives of Microbiology 104, 207-214.

Nissenbaum, A. (1975). The microbiology and biogeochemistry of the Dead Sea. Microbial Ecology 2, 139161.

OREN, A. (1983a). Halobacterium sodomense spec. nov., a Dead Sea Halobacterium with an extremely high magnesium requirement. International Journal of Systematic Bacteriology 33, 381-386.

OREN, A. (1983b). Clostridium lortetii spec. nov., a halophilic obligatory anaerobic bacterium producing endospores with attached gas vacuoles. Archives of Microbiology 136, 42-48.

Oren, A., Paster, B. J. \& Woese, C. R. (1984a). Haloanaerobiaceae: a new family of moderately halophilic obligatory anaerobic bacteria. Systematic and Applied Microbiology 5, 71-80.

Oren, A., Weisburg, W. G., Kessel, H. \& Woese, C. R. (1984b). Halobacteroides halobius gen. nov., spec. nov., a moderately halophilic anaerobic bacterium from the bottom sediments of the Dead Sea. Systematic and Applied Microbiology 5, 58-70.

PosT, F. J. (1977). The microbial ecology of the Great Salt Lake. Microbial Ecology 2, 139-161.

Quesada, E., Ventosa, A., Rodriguez-Valera, F., Megias, L. \& Ramos-Cormenzana, A. (1983). Numerical taxonomy of moderately halophilic Gram-negative bacteria from hypersaline soils. Journal of General Microbiology 129, 2649-2657.

Quesada, E., Ventosa, A., Ruiz-Berraquero, F. \& Ramos-Cormenzana, A. (1984). Deleya halophila, a new species of moderately halophilic bacteria. International Journal of Systematic Bacteriology 34, 287-292.

Quesada, E., Bejar, V., Valderrama, M. J., Ventosa, A. \& Ramos-Cormenzana, A. (1985). Isolation and characterization of moderately halophilic nonmotile rods from different saline habitats. Microbiologia 1, 89-96.

Rodriguez-Valera, F., Ruiz-Berraquero, F. \& RAMOS-CORMENZANA, A. (1979). Isolation of extreme halophiles from seawater. Applied and Environmental Microbiology 38, 164-165.

Rodriguez-Valera, F., Ruiz-Berraquero, F. \& Ramos-CoRmenzana, A. (1981). Characteristics of the heterotrophic bacterial populations in hypersaline environments of different salt concentrations. Microbial Ecology 7, 235-243.

Rodriguez-Valera, F., Juez, G. \& Kushner, D. J. 
(1983). Halobacterium mediterranei spec. nov., a new carbohydrate-utilizing extreme halophile. Systematic and Applied Microbiology 4, 369-381.

Rodriguez-Valera, F., Ventosa, A., Juez, G. \& IMHOFF, J. F. (1985). Variation of environmental features and microbial populations with salt concentrations in a multi-pond saltern. Microbial Ecology 11, 107-115.

RÜGER, H. J. (1983). Differentiation of Bacillus globisporus, Bacillus marinus comb. nov., Bacillus aminovorans, and Bacillus insolitus. International Journal of Systematic Bacteriology 33, 157-161.

RÜGER, H. J. \& RICHTER, G. (1979). Bacillus globisporus subsp. marinus subsp. nov. International Journal of Systematic Bacteriology 29, 196-203.

SiEburth, J. McN. (1979). Sea Microbes. Oxford \& New York: Oxford University Press.

SNEATH, P. H. A. \& Johnson, R. (1972). The influence on numerical taxonomic similarities of errors in microbiological tests. Journal of General Microbiology 72, 377-392.

SNeath, P. H. A. \& Sokal, R. R. (1973). Numerical Taxonomy. The Principles and Practice of Numerical Classification. San Francisco: Freeman.

SoKal, R. R. \& Michener, C. D. (1958). A statistical method for evaluating systematic relationships. University of Kansas Science Bulletin 38, 1409-1438.

Torreblanca, M., Rodriguez-Valera, F., Juez, G., Ventosa, A., Kamekura, M. \& Kates, M. (1986).
Classification of non-alkaliphilic halobacteria based on numerical taxonomy and polar lipid composition, and description of Haloarcula gen. nov. and Haloferax gen. nov. Systematic and Applied Microbiology 8, 89-99.

Ventosa, A., Quesada, E., Rodriguez-Valera, F., Ruiz-Berraquero, F. \& Ramos-Cormenzana, A. (1982). Numerical taxonomy of moderately halophilic Gram-negative rods. Journal of General Microbiology 128, 1959-1968.

Ventosa, A., Ramos-Cormenzana, A. \& Kocur, M. (1983). Moderately halophilic Gram-positive cocci from hypersaline environments. Systematic and Applied Microbiology 4, 564-570.

Ventosa, A., Rodriguez-Valera, F., Poindexter, J. S. \& RezNIKofF, W. S. (1984). Selection for moderately halophilic bacteria by gradual salinity increases. Canadian Journal of Microbiology 30, 1279-1282.

WEEKs, O. B. (1974). Genus Flavobacterium. In Bergey's Manual of Determinative Bacteriology, 8th edn, pp. 357-363. Edited by R. E. Buchanan \& N. E. Gibbons. Baltimore: Williams \& Wilkins.

Zeikus, J. G., HegGe, P. W., Thompson, T. E., Phelps, T. J. \& Langworthy, T. A. (1983). Isolation and description of Haloanaerobium praevalens gen. nov. and spec. nov., an obligately anaerobic halophile common to Great Salt Lake sediments. Current Microbiology 9, 225-234. 